\title{
Exploratory analysis of nutrient concentrations in Eucalyptus leaf color patterns
}

\author{
Luiz Felipe Ramalho de Oliveira $\otimes^{1 *}$ Reynaldo Campos Santana $\bigotimes^{1}$
}

${ }^{1}$ Universidade Federal dos Vales do Jequitinhonha e Mucuri, , Departamento de Engenharia Florestal, Campus JK, Rodovia MGT 367 - Km 583, Alto da Jacuba, n5000, CEP 39100-000, Diamantina, MG, Brasil.

\section{Original Article \\ *Corresponding author: luizfelipe.florestal@gmail.co $\mathrm{m}$}

Keywords:

Leaf senescence

Remobilization

Munsell color

Visual diagnosis

Palavras-chave:

Senescência foliar

Remobilização

Coloração Munsell

Diagnose visual

Received in

$2019 / 07 / 17$

Accepted on

2020/03/11

Published in

2020/06/30

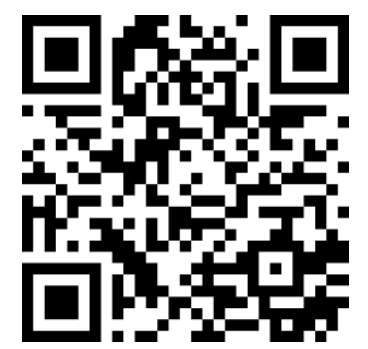

DOI:

https://doi.org/10.34062/afs. v7i2.8647

\section{(cc) BY}

ABSTRACT: The aim of this study was to evaluate the use of leaf color pattern to analyze leaf nutrient concentrations in Eucalyptus leaves and to establish relationships between color patterns and leaf nutrient concentrations using two exploratory analysis. The study was carried out in Eucalyptus stands at 25 months old using leaves from the lower of tree crowns classified into five color patterns of Munsell color charts for plant tissues. The principal component analyses and the self-organizing maps were used to aid in the classification of samples in leaf color patterns. Subsequently, the k-means cluster algorithm was performed. In principal component analysis, the $7.5 \mathrm{GY} 8 / 8$ leaf color pattern stood out from the others and it was mainly influenced by nitrogen, phosphorous, copper, and potassium concentrations. The samples of $7.5 \mathrm{GY} 8 / 4$ leaf color pattern did not present a great nitrogen, phosphorous, sulfur, copper and potassium concentrations as the $7.5 \mathrm{GY} 8 / 8$ neither a great manganese, calcium, boron, zinc and iron concentrations as others leaf color patterns. The self-organizing map provides a greater proximity between the $7.5 \mathrm{GY} 8 / 8$ and $7.5 \mathrm{GY} 8 / 4$ leaf color patterns and the others leaf color patterns were randomly distributed in the Umatrix. Although the k-means algorithm presented two clusters in both analyses, the self-organizing map presented a slight superiority than principal component analysis. Using leaf color patterns was possible to infer about leaf nutrient concentrations in Eucalyptus. Both methods were able to distinguish only the healthy leaves $7.5 \mathrm{GY} 8 / 8$ from those whose were in the leaf senescence process.

\section{Análise exploratória da concentração de nutrientes em padrões de coloração foliar de Eucalyptus}

RESUMO: O objetivo deste estudo foi avaliar o uso de padrões de coloração foliar para analisar concentrações de nutrientes foliares em folhas de Eucalyptus e estabelecer relações entre estes padrões e concentrações de nutrientes foliares por meio de duas análises exploratórias. $\mathrm{O}$ estudo foi realizado em plantios de Eucalyptus com 25 meses de idade, classificando folhas da região basal da copa em cinco padrões da Carta de Munsell para tecidos foliares. As Análise de Componentes Principais e Mapas Auto-organizáveis foram utilizadas para classificar amostras em padrões de colorações foliares, o padrão de coloração 7.5 GY 8/8 diferenciou dos outros padrões, principalmente influenciado pelas concentrações de nitrogênio, fósforo, cobre e potássio. As amostras com padrão de coloração 7.5 GY 8/4 não apresentou altas concentrações de nitrogênio, fósforo, enxofre, cobre e potássio como as folhas do padrão $7.5 \mathrm{GY}$ 8/8 nem altas concentrações de manganês, cálcio, boro, zinco e ferro como os demais padrões de coloração. Pelos mapas auto-organizáveis apresentaram maior proximidade entre os padrões de coloração 7.5 GY 8/8 e 7.5 GY 8/4, enquanto os demais padrões de coloração foram distribuídos aleatoriamente na matriz U. Embora o algoritmo k-médias apresentou dois agrupamentos em ambas análises, os mapas auto-organizáveis apresentaram ligeira superioridade em relação a análise de componente principais. Pelo uso de padrões de coloração foliar foi possível inferir sobre as concentrações de nutrientes foliares em Eucalyptus. Ambos métodos foram capazes de distinguir folhas saudáveis $7.5 \mathrm{GY}$ 8/8 dos demais padrões de coloração em processo de senescência foliar. 


\section{Oliveira \& Santana}

\section{Introduction}

The Eucalyptus, a relevant tree for Brazilian timber production, contributed $\mathrm{R} \$ 71.1$ billion to the country's gross domestic product in 2016 (Ibá 2017). These species undergo different development and growth stages during its stand growing season. In general, all fertilizations in Eucalyptus stands are performed with their respective nutritional management up to 24 months old (Santana et al. 2014). Since then, the canopy closure and nutrients cycling start and, along with fertilizations previously carried out, are enough to ensure production until the stem cutting with approximately seven years old. Due to this, the leaf senescence process in crown basal leaves begins with the canopy closure.

The leaf senescence is a process of leaf cell disruption with traits and ions mobilization released during the process (Thomas and Stoddart 1980; Maillard et al. 2015). Leaf nutrients with greater mobility in phloem are translocate from senescent leaves to young tissues in plants (Himelblau and Amasino 2001; Avice and Etienne 2014). In addition, protein and chlorophyll concentrations decrease in senescent leaves causing leaf yellowing (Hörtensteiner and Krãutler 2011).

The leaf yellowing occurs gradually as the leaf senescence process progresses. Although this process is gradual, it is possible to describe changes in leaf color patterns over time. The use of leaf color patterns can be useful to relate to nutrient concentrations and their translocation dynamics (Karcher and Richardson 2003; Raese et al. 2007). Although the senescence is a normal process in Eucalyptus stands and has not direct relationship in normal conditions with health plants, color patterns in senescent leaves can indicate different nutrient concentrations and them dynamics in plant metabolism, even in leaves in another crown positions.

However, there are many relationships between nutrients within plant and the translocation processes do not act individually in each nutrient (Maillard et al. 2015). In view of these complex relationships, the visual diagnosis in senescent leaves based on only one nutrient as determinant in leaf color patterns is not feasible. Therefore, the use of techniques that considers concentrations of more than one nutrient at the same time are most appropriate to verify their influences in each leaf color pattern.

In addition, as the color determination is subjective of the observer, the leaf color pattern establishment can be widely used to improve the assertiveness of leaf visual analysis. The visual analysis of soil coloration using the Munsell color chart is an accepted and validated methodology with wide application in soil science. Although less widespread than soil Munsell color chart, there is also a Munsell color charts for plant tissues
(MCCPT) (GretagMacbeth LLC, New Windsor, NY).

The MCCPT is based on a three-dimensional system with the idea of each color has three parameters or attributes. The first is the color perception known as hue and the tonality range in visible region of electromagnetic spectrum, from violet to intense red. The second is value, which is the luminous intensity of the color ranging from 10 to pure white until zero to pure black. The last is the color saturation chroma, assuming low values for weak colors and high values for bright colors. Similar to the use of Munsell color chart to soil analysis, it is expected that the use of MCCPT may be widely used in leaf visual analysis in field conditions, establishing leaf color patterns as nutrient concentrations indicatives.

Therefore, the aim of this study was to evaluate the use of leaf color pattern to analyze leaf nutrient concentrations in Eucalyptus and to establish relationships between color patterns and leaf nutrient concentrations.

\section{Material and Methods}

The study was carried out in Eucalyptus stands at 25 months old, established at $7.0 \times 1.3 \mathrm{~m}$ tree spacing, with three clones (E. urophylla $\mathrm{x} E$. grandis: GG680, E. urophylla x E. grandis: GG682 and hybrid of E. urophylla ST Blake: I144). In these stands nine plots of 10 ha were allocated, three per clone. In each of the nine plots, a sample was collected for each color pattern (five patterns), totaling 45 samples. For sample composition, one leaf was collected from 30 plants randomly selected in zigzag walk. Leaves from the lower of tree crowns were visually classified into five color patterns MCCPT (Gretag-Macbeth, New Winsor, NY, USA). The leaf color patterns were defined by the clear expression of the biochemical cycling of nutrients (Saur et al. 2000) (Table 1).

The composite samples were placed in paper bags and oven-dried with forced air circulation at $65^{\circ} \mathrm{C}$. After drying, the 45 composite samples were digested in nitro-perchloric solution and the concentrations of calcium $(\mathrm{Ca})$, magnesium $(\mathrm{Mg})$, sulfur $(\mathrm{S})$, zinc $(\mathrm{Zn})$, iron $(\mathrm{Fe})$ and manganese $(\mathrm{Mn})$ determined by spectrophotometry. The phosphorus concentration (P) was determined by colorimetry, the potassium concentration $(\mathrm{K})$ by flame photometry and the total nitrogen concentration $(\mathrm{N})$ by the Kjeldahl method after sulfuric digestion.

To aid in the classification of samples in leaf color patterns determined by MCCPT, the Principal Component Analyses (PCA) and the SelfOrganizing Maps (SOM) were used. PCA was used in order to reduce the dimensionality of the data, to analyze the influence of the nutrients on the leaf color patterns and to visualize the samples clusters tendency. The PCA reduce the data dimensionality 
Table 1. Leaf color pattern sampled in Eucalyptus stands

\begin{tabular}{llllll}
\hline Color name diagrams & Matte color chips & Hue & Value & Chroma & Munsell color code \\
\hline Brilliant yellow green & $7.5 \mathrm{GY}$ & 8 & 8 & $7.5 \mathrm{GY} 8 / 8$ \\
Light yellow green & $7.5 \mathrm{GY}$ & 8 & 4 & $7.5 \mathrm{GY} 8 / 4$ \\
Brown & $7.5 \mathrm{YR}$ & 4 & 2 & $7.5 \mathrm{YR} 4 / 2$ \\
Yellow & $2.5 \mathrm{Y}$ & 7 & 6 & $2.5 \mathrm{Y} 7 / 6$ \\
Strong yellow & & & & $2.5 \mathrm{Y} 8 / 10$ \\
\hline
\end{tabular}

by generating new variables by the linear combination of the initial variables. The PCA presents theses new variables in $\mathrm{k}$ dimension always smaller than of $\mathrm{d}$ dimension (nutrient numbers analyzed). The set of new dimensions generated are called as Principal Components (PCs) and each PC is directed to maximum variance. In this research, ellipses were used in the scatterplot to delimit the influence area of sample groups with probability of $95 \%$.

Similar to PCA, the SOM was also used to verify the influence of leaf nutrient concentrations in leaf color patterns and analyze the sample clusters tendency. SOM is a type of artificial neural network firstly proposed by Kohonen (1982) based on the winning neuron. The SOM groups samples with similar patterns from high dimensional input space in a non-linear fashion onto a low-dimensional space with outputs arranged in neurons grid (Kohonen 2001). Its architecture is formed only by input and output layers completely connected to each other by weights that fit in each iteration. In this study, we used the Gaussian neighborhood function and a hexagonal grid with 5x9 neurons, performing 1000 iteration to analyze the algorithm at a learning rate range of 0.05 until 0.01 (Equation 1).

$N_{j^{*} j}(t)=e^{\frac{\left\|r_{j^{*}-r_{j}}\right\|^{2}}{2 \sigma^{2}(t)}}$

wherein: $N_{j * j}(t)$ is the neighborhood function of winning neuron $j^{*}$ on iteration $t ; \sigma^{2}(t)$ is the neighborhood radius on iteration $t ;\left\|r_{j^{*}}-r_{j}\right\|^{2}$ is the distance between $j^{*}$ and $j$ neurons in the grid.

After PCA and SOM, the k-means cluster analysis was performed with 1000 iterations and selecting the number of clusters by the reducing sum of squares within clusters and the number of leaf color patterns. All graphs and statistical procedures were carried out using the software R Core Team (2017) version 3.4.0, platform support R Studio version 1.0.143.

\section{Results and discussion}

The PCA presented two PCs explaining around $70 \%$ of total variance (Figure 1). Due to this and the small percentage of increase including three PCs or more, only two PCs were chosen.

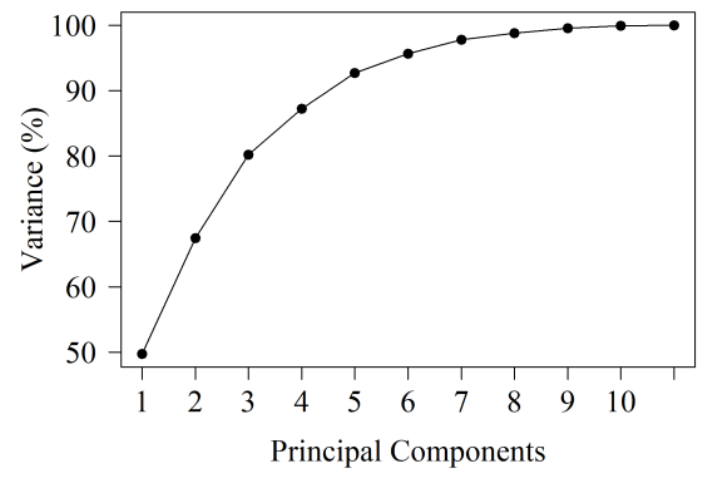

Figure 1. Variance explained by principal components.

It was verified strong correlation between $\mathrm{N}$, $\mathrm{P}, \mathrm{S}$ and $\mathrm{Cu}$ concentrations and $\mathrm{PC} 1$ by the eigenvector of the first two PCS (Equation 2). Similarly, the PC2 was strong correlated with $\mathrm{K}, \mathrm{Ca}$, $\mathrm{Fe}, \mathrm{Mn}$ and $\mathrm{Cu}$ concentrations (Equation 3). $\mathrm{Mg}$ and $\mathrm{Zn}$ concentrations were less correlated with both PCs (Equations 2 and 3). Although not highlighted in any $\mathrm{PC}$, the $\mathrm{B}$ concentrations were reasonable correlated in both PCs (PC1: 0,29 e PC2: 0,25). 


\section{Oliveira \& Santana}

In the scatterplot with the first two PCs it can visualize the dispersion of the leaf color pattern and the influence of leaf nutrient concentrations in their samples (Figure 2a). The 7.5 GY 8/8 leaf color pattern stood out from the others and it was mainly influenced by $\mathrm{N}, \mathrm{P}, \mathrm{S}, \mathrm{Cu}$ and $\mathrm{K}$ concentrations. The samples of $7.5 \mathrm{GY} 8 / 4$ leaf color pattern were allocated in an intermediate region on scatterplot, where $\mathrm{Mg}$ and $\mathrm{Zn}$ concentrations were determinants for their location. It is possible to affirm that this leaf color pattern did not present a great $\mathrm{N}, \mathrm{P}, \mathrm{S}, \mathrm{Cu}$ and $\mathrm{K}$ concentrations as the $7.5 \mathrm{GY} 8 / 8$ neither a great $\mathrm{Mn}, \mathrm{Ca}$, Band Fe concentrations as other leaf color

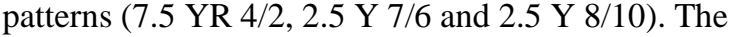
7.5 YR 4/2, 2.5 Y 7/6 and 2.5 Y 8/10 leaf color patterns were dispersed in the scatterplot under the influence mainly of $\mathrm{Ca}, \mathrm{Mn}, \mathrm{B}$, and $\mathrm{Fe}$ concentrations, it was not possible to separate them by ellipses at $95 \%$ probability.

During leaf senescence, the concentration of greater phloem mobility leaf nutrients such as $\mathrm{N}, \mathrm{P}$ and $\mathrm{K}$ tend to decrease and the concentration of lower phloem mobility nutrients such as $\mathrm{Mn}, \mathrm{Ca}$ and $\mathrm{Mg}$ tend to increase (Saur et al. 2000; Marschner

a)

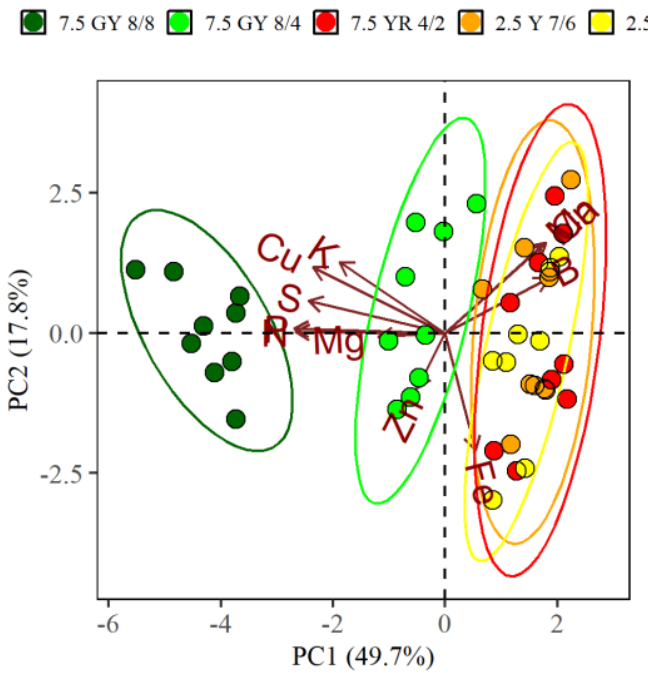

2011). Thus, leaf color patterns inherent to advanced senescence stages such as $7.5 \mathrm{YR} 4 / 2,2.5 \mathrm{Y} 7 / 6$ and $2.5 \mathrm{Y} 8 / 10$ tend to have lower concentration of mobile nutrients (Saur et al. 2000; Maillard et al. 2015). Similarly, leaf color patterns of healthy leaves as 7.5 GY 8/8 and 7.5 GY 8/4 present higher concentration of mobile nutrients.

The correlation between some leaf nutrient concentrations were strong. Mainly between $\mathrm{N}$ and $\mathrm{P}$ concentration, with great influence on leaf color pattern 7.5 GY 8/8 (Figure 2 a). The $\mathrm{N}$ and $\mathrm{P}$ act directly in photosynthetic relationships and influence the leaf pigment concentrations (Pimestein et al. 2005; Marschner 2011). Therefore, intense green leaves present higher concentrations of these nutrients and, consequently, higher chlorophyll concentrations also (Gitelson and Merzlyak, 1994; Clevers and Gitelson 2013; Oliveira et al. 2017). Moreover, it is visual the strong correlation between leaf $\mathrm{Ca}$ and $\mathrm{Mn}$ concentrations and their influence in leaf color patterns in advanced senescence stages (7.5 YR 4/2, $2.5 \mathrm{Y} 7 / 6$ and $2.5 \mathrm{Y}$ 8/10). Both nutrients are mobilized from roots to shoot during the senescence process (Mailard et al., 2015).

b)

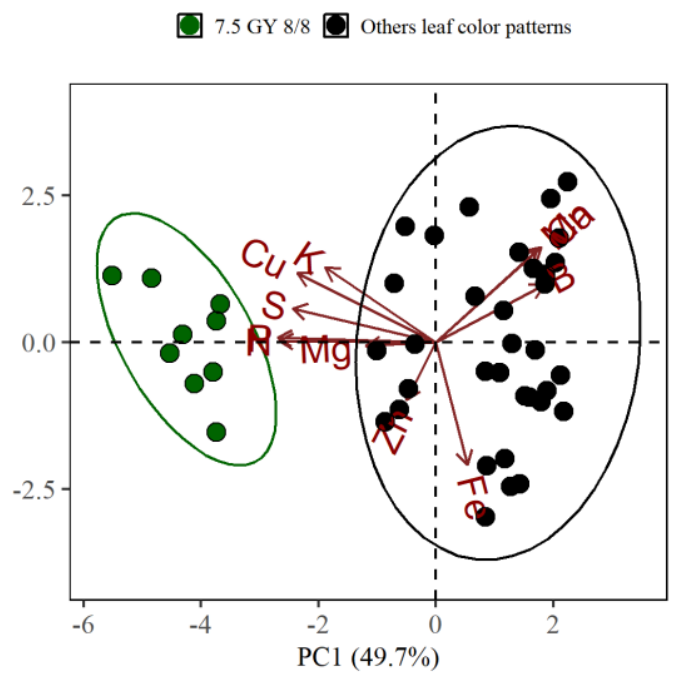

Figure 2. Scatterplot between the first and second principal component (PC1 and PC2). a) Leaf color pattern samples. b) Groups formed by k-means algorithm. N: Nitrogen; P: Phosphorus; K: Potassium; Ca: Calcium; Mg: Magnesium; S: Sulfur; B: Boron; Zn: Zinc; Fe: Iron; Mn: Manganese; Cu: Copper.

Based on the reducing sum of square within the clusters and the cluster tendency, there were two clusters by $\mathrm{k}$-means algorithm (Figure $3 \mathrm{a}$ ). A cluster was formed by the leaf color pattern $7.5 \mathrm{GY} 8 / 8$, mainly influenced by the concentration of greater mobility nutrients: $\mathrm{N}, \mathrm{P}, \mathrm{K}, \mathrm{Mg}, \mathrm{S}$ and $\mathrm{Cu}$. Another cluster formed by the others leaf color patterns influenced by the concentration of lower mobility nutrients: $\mathrm{Ca}, \mathrm{Mn}, \mathrm{B}, \mathrm{Fe}$ and $\mathrm{Zn}$ (Figure 2b). As in PCA, the SOM provides a greater proximity between the $7.5 \mathrm{GY} 8 / 8$ and $7.5 \mathrm{GY} \mathrm{8/4} \mathrm{leaf} \mathrm{color} \mathrm{patterns}$ (Figure 4 a). In addition, the others leaf color patterns were randomly distributed in the U-matrix and not presented clusters determined by respective color patterns. By the sum of squares within clusters the same clusters of PCA were found by SOM (Figure $3 \mathrm{~b}, 4 \mathrm{~b})$. Although the k-means algorithm presented two clusters in both analyses, the sum of squares within clusters in the SOM presented lower valuer than PCA. Therefore, the SOM presented a slight superiority in the data dimensionality reducing and classification of leaf color pattern compared to PCA. In general, similar results testing both techniques presenting slight superiority of SOM has been reported (Brosse et al. 2001; Chon et al. 2010). 


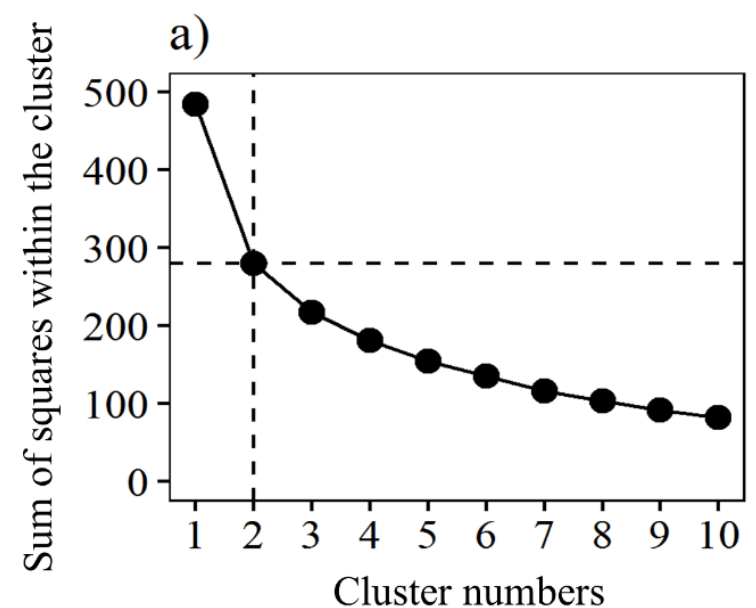

b)

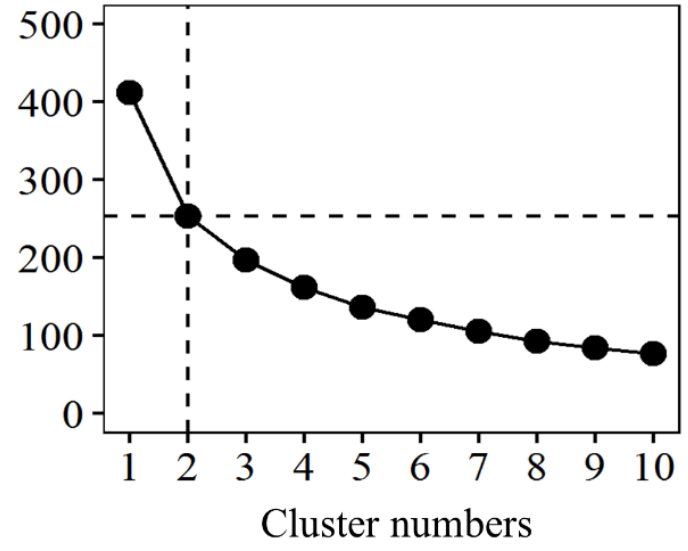

Figure 3. Sum of squares within the cluster by k-means algorithm. a) Choosing cluster numbers by k-means to Principal Component Analysis (PCA). b) Choosing cluster numbers by k-means to Self-Organizing Maps (SOM).

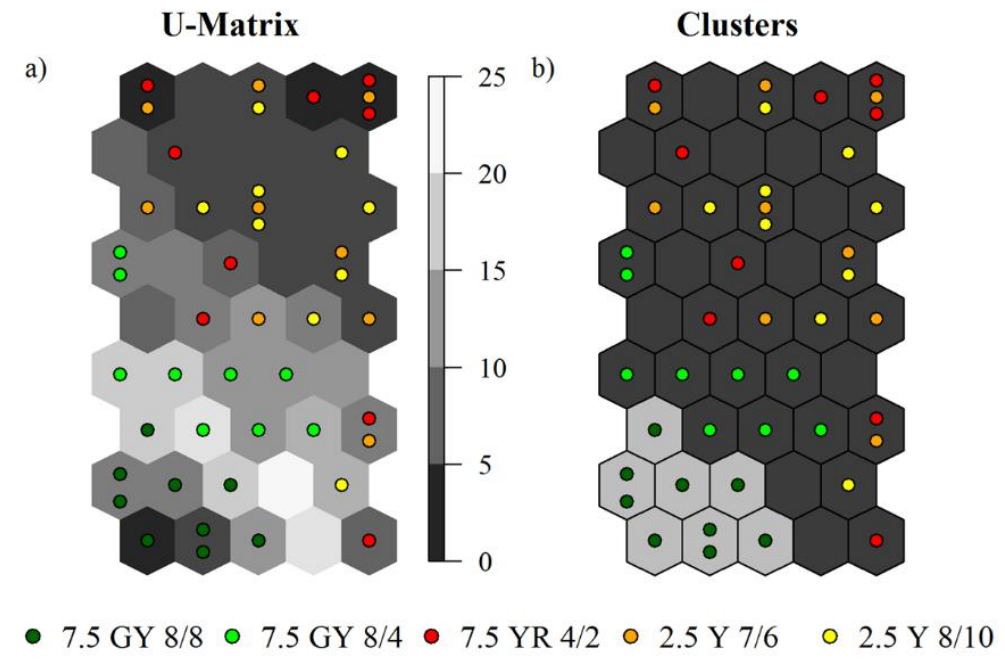

Figure 4. Self-Organizing Maps (SOM). a) U-matrix. b) Cluster by k-means algorithm.

By SOM it is possible to verify the greater influence of $\mathrm{N}, \mathrm{P}, \mathrm{K}, \mathrm{S}$ and $\mathrm{Cu}$ concentrations in 7.5 GY 8/8 leaf color pattern (Figure 4a; Figure 5). Likewise, the influence of $\mathrm{B}, \mathrm{Ca}$ and $\mathrm{Mn}$ in 7.5 YR 4/2, 2.5 Y $7 / 6$ and 2.5 Y 8/10 leaf color patterns located in the upper left of U-matrix, similar result observed in PCA (Figure 2a, 4a, 5). However, as observed by Kalteh et al. (2008) and Chon et al. (2011), the influence of some variables becomes more visible in SOM analyses. For example, the influence of Fe concentration on 7.5 YR 4/2 and 2.5 Y 8/10 was verified by SOM, by samples located in right region of U-matrix. As well as the influence of Zn concentration, which could not clearly detect by PCA, that influenced samples in lower right region on U-matrix. Moreover, by SOM its possible verified the influenced egalitarian of $\mathrm{Mg}$ concentration in every neuron in U-matrix grid (Figure 5). 


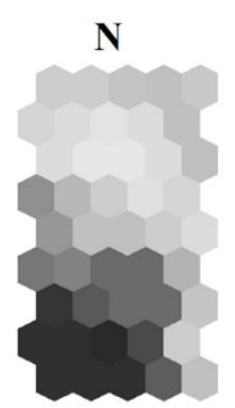

B

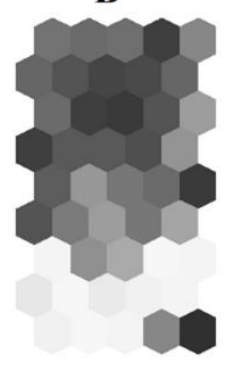

$\mathbf{P}$

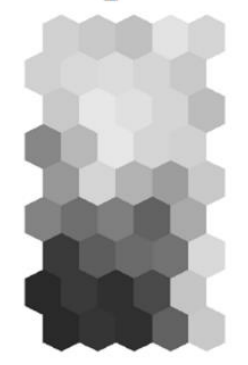

Zn

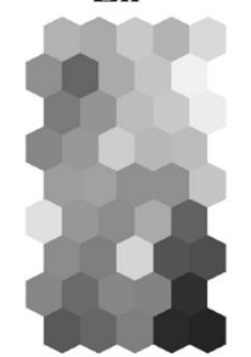

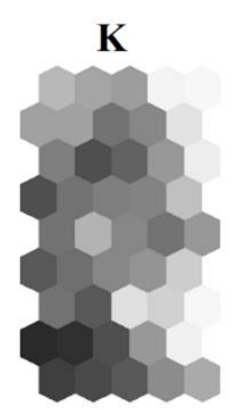

$\mathrm{Fe}$

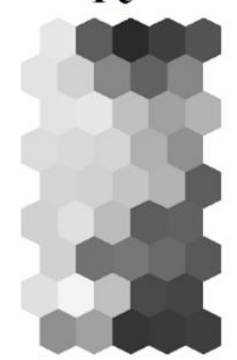

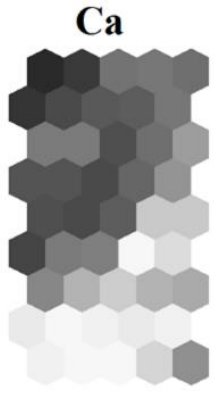

Mn

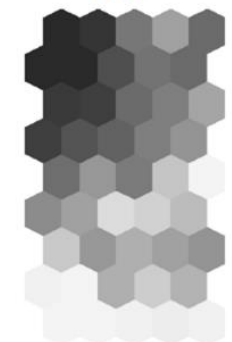

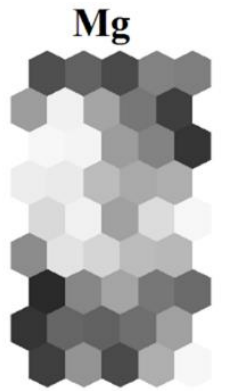

$\mathrm{Cu}$

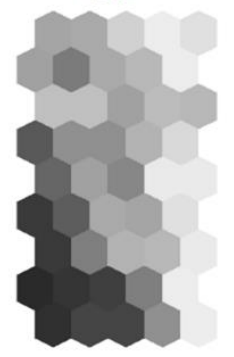

$\mathbf{S}$

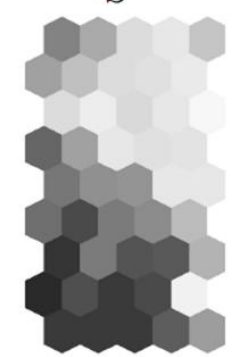

$\left[\begin{array}{l}1.0 \\ -0.8 \\ -0.6 \\ -0.4 \\ -0.2 \\ 0.0\end{array}\right.$

Figure 5. Leaf nutrient concentrations influence in SOM. N: Nitrogen; P: Phosphorus; K: Potassium; Ca: Calcium; Mg: Magnesium; S: Sulfur; B: Boron; Zn: Zinc; Fe: Iron; Mn: Manganese; Cu: Copper.

\section{Conclusions}

By the use of leaf color patterns determined by MCCPT it was possible to infer about leaf nutrient concentrations in Eucalyptus. The 7.5 GY $7 / 8$ leaf color pattern present higher concentrations of greater mobility nutrients and lower concentrations of lower mobility nutrients compared to $7.5 \mathrm{GY} 8 / 4,7.5$ YR 4/2, 2.5 Y 7/6 and 2.5 Y 8/10 leaf color patterns. While 7.5 YR 4/2, 2.5 Y $7 / 6$ and $2.5 \mathrm{Y}$ 8/10 leaf color patterns presented higher concentrations of lower mobility nutrients and lower concentrations of lower mobility nutrients.

Despite leaf color pattern classification in only two clusters, the SOM presented a slight classification superiority in relation to PCA. However, both methods were able to distinguish only the healthy leaves $7.5 \mathrm{GY} 8 / 8$ from those whose were in the leaf senescence process.

\section{Acknowledgements}

This study was financed in part by the Coordenação de Aperfeiçoamento de Pessoal de Nível Superior - Brasil (CAPES) - Finance Code 001, Universidade Federal dos Vales do Jequitinhonha e Mucuri (UFVJM), Conselho Nacional de Desenvolvimento Científico e Tecnológico (CNPq), Fundação de Amparo a Pesquisa de Minas Gerais (FAPEMIG), and Gerdau Florestal SA.

\section{References}

Avice J-CC, Etienne P (2014) Leaf senescence and nitrogen remobilization efficiency in oilseed rape (Brassica napus L.). Journal of Experimental Botany, 65:3813-3824. doi: 10.1093/jxb/eru177.
Brosse S, Giraudel JL, Lek S (2001) Utilisation of non-supervised neural networks and principal component analysis to study fish assemblages. Ecological Modelling, 146:159-166. doi: 10.1016/S0304-3800(01)00303-9.

Clevers JGPW, Gitelson AA (2001) Remote estimation of crop and grass chlorophyll and nitrogen content using red-edge bands on Sentinel-2 and -3. International Journal of Applied Earth Observation and Geoinformation, 23:344-351. doi: 10.1016/j.jag.2012.10.008.

Chon T-S (2011) Self-Organizing Maps applied to ecological sciences. Ecological Informatics, 6:5061. doi: 10.1016/j.ecoinf.2010.11.002.

Ebensen KH (2002) Multivariate data analysis: In practice. $5^{\text {th }}$ Edition. Oslo: CAMO Process AS. 587 p.

Gitelson AA, Merzlyak, MN, Lichtenthaler HK (1996) Detection of red edge position and Chlorophyll. Journal Plant of Physiology, 148:501508. doi: 10.1016/S0176-1617(96)80285-9.

Himelblau E, Amasino RM (2001) Nutrients mobilized from leaves of Arabidopsis thaliana during leaf senescence. Journal of Plant Physiology, 158:1317-1323. doi: 10.1078/0176-1617-00608.

Hörtensteiner S, Kräutler B (2011) Chlorophyll breakdown in higher plants. Biochimica et Biophysoca Acta, 1807:977-988. doi: 10.1016/j.bbabio.2010.12.007.

Ibá - Industria Brasileira De Árvores. Relatório anual da IBÁ 2017, ano base 2016. 2017. 80 p. 


\section{Oliveira \& Santana}

Kalteh AM, Hjorth P, Berndtsson R (2008) Review of the self-organizing map (SOM) approach in water resources: Analysis, modelling and application. Environmental Modelling \& Software, 23:835-845. doi: 10.1016/j.envsoft.2007.10.001

Karcher DE, Richardson MD (2003) Quantifying turfgrass color using digital image analysis. Crop Science, 43:943-951. doi: 10.2135/cropsci2003.9430.

Kohonen T (1982) Self-organized formation of topologically correct feature maps. Biological Cybernetics, 43:59-69. doi: 10.1007/BF00337288.

Kohonen T (2001) Self-organizing maps. $3^{\text {rd }}$ Edition. Berlin: Springer. $501 \mathrm{p}$.

Marschner H (2011) Marschner's mineral nutrition of higher plants. London: Academic Press. 651 p.

Maillard A, Diguélou S, Billard V, Laine P, Garnica M, Prudent M, Garcia-Mina JM, Yvin JC, Ourry A (2015) Leaf mineral nutrient remobilization during leaf senescence and modulation by nutrient deficiency. Frontiers in Plant Science, 6:1-15, 2015. doi: 10.3389/fpls.2015.00317.

Oliveira LFR, Oliveira MLR, Gomes FS, Santana RC (2017) Estimating foliar nitrogen in Eucalyptus using vegetation indexes. Scientia Agricola, 74:142147. doi: 10.1590/1678-992x-2015-0477.
Pimstein A, Karnieli A, Bansal SK, Bonfil DJ (2011) Exploring remotely sensed technologies for monitoring wheat potassium and phosphorus using field spectroscopy. Field Crops Research, 121:125135. doi: 10.1016/j.fcr.2010.12.001.

$\mathrm{R}$ Core Team (2017). R: A language and environment for statistical computing. R Foundation for Statistical Computing, Vienna, Austria. URL http://www.R-project.org/.

Raese JT, Drake SR, Curry EA (2011) Nitrogen fertilizer influences fruit quality, soil nutrients and cover crops, leaf color and nitrogen content, biennial bearing and cold hardiness of 'golden delicious'. Journal of Plant Nutrition, 30:1585-1604. doi: 10.1080/01904160701615483.

Santana RC, Fontan ICI, Oliveira SL (2014) Implantação, manutenção e produtividade dos povoamentos. In: Vale $\mathrm{AB}$, Machado $\mathrm{CC}$, Pires JMM, Vilar MB, Costa CB, Nacif AP (ed) Eucaliptocultura no Brasil: Silvicultura, Manejo e Ambiência. Belo Horizonte: Suprema. p. 161-186.

Saur E, Nambiar EKS, Fife DN (2000) Foliar nutrient retranslocation in Eucalyptus globulus. Tree Physiology, 20:1105-1112. doi: 10.1093/treephys/20.16.1105.

Thomas H, Stoddart JL (1980) Leaf senescence. Annual Review of Plant Physiology, 31:83-111. doi: 10.1146/annurev.pp.31.060180.000503. 